\title{
Recent Great Depressions: Aggregate Growth in New Zealand and Switzerland
}

\author{
Timothy J. Kehoe and Kim J. Ruhl
}

As measured in the Penn World Tables, Switzerland had the highest income per capita in the world in 1970, and New Zealand the eighth. By 2000, Switzerland had fallen to eighth, and New Zealand had tumbled to twenty-second in the rankings. ${ }^{1}$ These changes are less an indication of the rapid growth in other countries than they are the lack of growth in New Zealand and Switzerland. Both New Zealand and Switzerland have lost about 30 percent of their output per working-age person, vis-à-vis the United States, over the last thirty years. In this paper, we analyze the growth of these two countries using the relatively new neoclassical depression methodology, which is based upon the standard neoclassical growth model.

Our results suggest that movements in total factor productivity (TFP) can largely explain the poor growth performance in New Zealand and Switzerland. Our growth accounting attributes almost the entire decline in output to changes in TFP and a relatively insignificant amount to changes in labor and capital inputs. We calibrate a simple dynamic general equilibrium model to the two countries and find that a model in which TFP is exogenous can explain about 96 percent of the decline in output for New Zealand and more than 100 percent of the decline for Switzerland.

In New Zealand, TFP grew on trend until it fell rapidly between 1974 and 1980, then leveled out, and now seems to be growing on a lower trend path. This observation is important in terms of the previous work on New Zealand's productivity. New Zealand underwent one of the most radical and complete set of market reforms in the late 1980s, including labor market reform, foreign trade liberalization, privatization of publicly owned enterprises, and tax reform. ${ }^{2}$ The importance of these reforms has focused much of the research on productivity in New Zealand to the period immediately before and after the implementation of the reforms. This line of research has 
been successful in evaluating the reforms and their effects and has provided valuable insight for policymakers. Our results suggest, however, that the economy of the 1970s and early 1980s needs to be more closely studied to understand the current situation.

Total factor productivity - as a residual after taking the impact of changes in capital and labor inputs out of changes in real output - includes the effects of a country's institutions, such as taxes, the legal system, and openness to foreign competition. Changes in institutions can change the growth path of TFP. The identification of these changes seems to be the key to understanding aggregate growth in New Zealand. A frequently cited candidate for the cause of New Zealand's poor performance is the decline of its terms of trade. (See, for example, Easton 1997, Chap. 5.) The beginning of the great depression in New Zealand coincides with its loss of favored access to markets of its major trade partner due to the United Kingdom's accession to the European Economic Community (EEC). Data show a subsequent sharp fall in the terms of trade and large changes in New Zealand's trade patterns. The resulting disruption in production patterns is a promising candidate explanation for the drop in TFP growth rates.

In Switzerland, TFP fell steadily compared to trend from 1973 to 1996, and this fall explains most of Switzerland's great depression. TFP and gross domestic product (GDP) grew at their respective trend rates following 1996, but do not appear to be returning to their previous trend paths. As in New Zealand, that TFP explains almost everything leaves us needing to explain TFP. In particular, we are left looking for the changing institutional factors that are reflected in our measurement of TFP. Switzerland's institutions include highly protected domestically oriented sectors such as telecommunications, agriculture, construction, and information technology. These sheltered sectors have had declining labor productivity, while the sectors exposed to competition have seen improvements. These facts are especially relevant considering Switzerland's failure to join the European Union, a move that would have forced many of these protected sectors to face international competition and European Union-mandated deregulation. Switzerland did begin a series of reforms aimed at increasing the competitiveness in these sectors as part of its revitalization plan, however. These reforms began to be implemented in the late 1990s and seem to coincide with the increased GDP and TFP growth rates found in the same period.

The next two sections outline the neoclassical depression methodology and its implementation. First we present the results of our growth accounting, and then we show how a calibrated growth model can reproduce the observed changes in output. We go on to discuss possible reasons for the decline in TFP for each country and suggest possible directions for future 
research on determining the causes of the modern great depressions in New Zealand and Switzerland.

\section{Neoclassical Depression Methodology}

Studying depressions using the neoclassical growth model is a relatively new methodology. Cole-Ohanian (henceforth, this is how we will refer to other papers in this volume) first applied the growth model to study the Great Depression of the 1930s in the United States. This successful application led to the study of depressions around the world using this method, including the depressions in Argentina (Kydland-Zarazaga), Canada (Amaral-MacGee), Chile and Mexico (Bergoeing et al.), France (Beaudry-Portier), Germany (Fisher-Hornstein), Italy (Perri-Quadrini), Japan (Hayashi-Prescott), and the United Kingdom (Cole-Ohanian).

We study a country's economic growth by measuring its real GDP per working-age person relative to a trend. (Details of the sources and construction of the data used in this paper are available in Appendix A.) We concentrate on GDP per working-age person instead of the more common per capita measure, since it is consistent with our theoretical economy in which the entire working-age population is capable of working. Because of the availability of data, we choose to count those aged 15-64 as the working-age population and, thus, most likely to be available for work. (We compare GDP per working-age person and GDP per capita in Appendix B.) We work with a Cobb-Douglas specification of the aggregate technology:

$$
Y_{t}=A_{t} K_{t}^{\alpha} L_{t}^{1-\alpha}
$$

where $A_{t}$ is TFP, $Y_{t}$ is GDP in year $t, K_{t}$ is the capital stock, and $L_{t}$ is hours worked. When TFP grows at a constant rate (that is, when TFP is $\left.A_{t}=\bar{A} g^{(1-\alpha) t}\right)$, the neoclassical growth model implies a unique balancedgrowth path in which output and capital per worker grow at the same constant rate, $g-1$. It is relative to this trend growth rate that we measure a country's performance.

Kehoe-Prescott argue that this trend growth in TFP represents the world stock of usable production knowledge growing smoothly over time and that this knowledge is not country-specific. We define the trend growth rate to be 2 percent per year, corresponding to the growth rate of GDP per workingage person for the United States over the period 1920-2000. Kehoe-Prescott consider the United States to be the best choice because it is a large, relatively stable country and because it is the current industrial leader. As shown in Figure 1, the 2 percent trend in GDP per working-age person fits the U.S. data very well, with the only major deviations from trend being the Great 
Figure 1. United States: GDP per working-age person

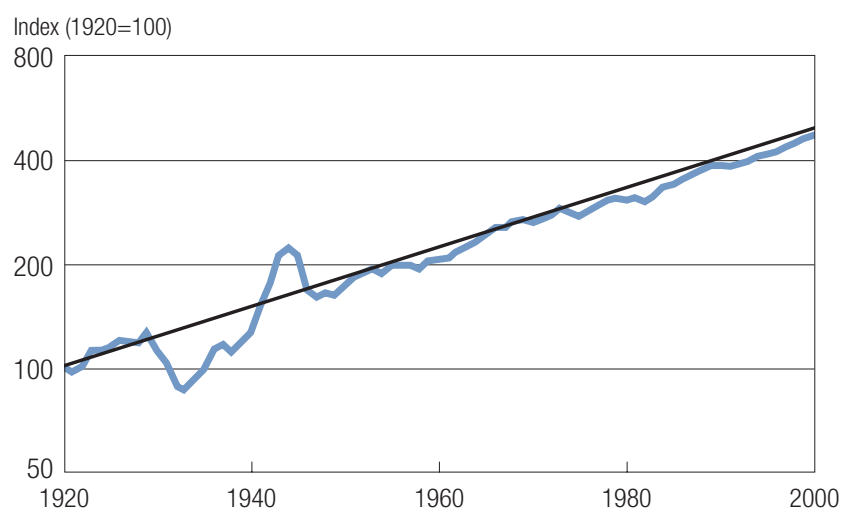

Depression, 1929-39, and the World War II buildup, 1939-46.

The stock of world production knowledge is common across countries, but countries differ in their institutional structures. This implies that, even though all countries on a balanced-growth path grow at the same rate, each country is on its own growth path. These paths differ in their levels of output per working-age person. Countries with institutions that encourage efficiency grow on a path with higher output per working-age person than countries with institutions that encourage rent seeking or other activities that lower efficiency. The institutions that determine these paths include competition policy, bankruptcy systems, and the legal system. The parts of these institutions that affect neither labor input nor the accumulation of capital are captured in TFP. Changing institutions changes the path of TFP, moving a country to a new balanced-growth path. One of the central premises of the neoclassical depression methodology is that explaining movements in TFP involves identifying the changing institutions.

Figures 2 and 3 display output per working-age person for New Zealand and Switzerland for 1920-2000. Though our analysis is restricted to the recent great depressions in New Zealand and Switzerland, the long-term movements in a country provide interesting perspective. As is shown in Figure 2, New Zealand grew on its 2 percent balanced-growth path from about 1938 to 1974, before falling sharply below trend. The period 1929-32 is what New Zealand economic historians refer to as "the Depression" (Hawke 1985). This episode was marked by a sharp drop below trend, followed by a quick recovery. In contrast, the recent great depression has been slower to develop, but GDP per working-age person has deviated more from trend, and for a much longer period. In Switzerland, we see a different pattern. Switzerland 
Figure 2. New Zealand: GDP per working-age person

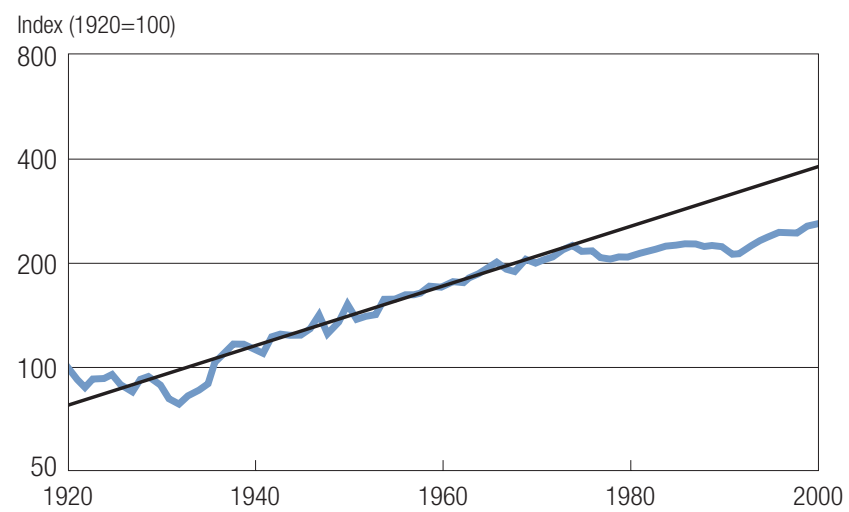

Figure 3. Switzerland: GDP per working-age person

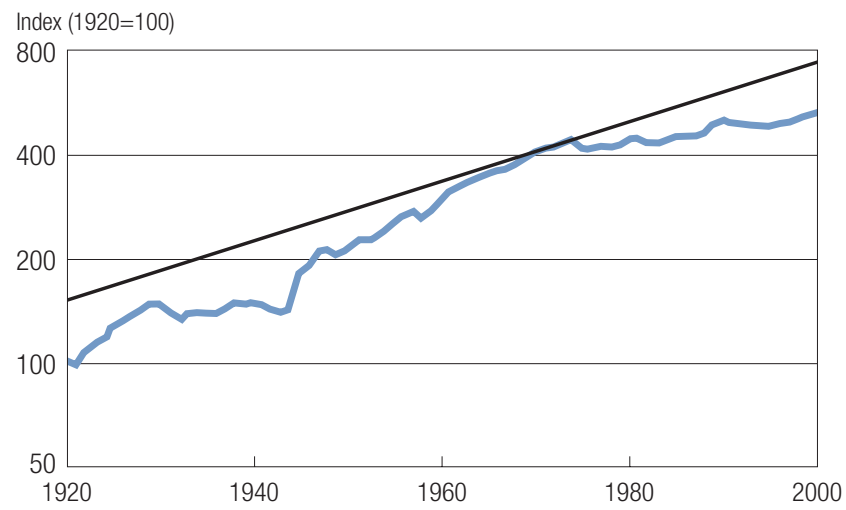

experienced almost no growth from 1930 to 1944, which is significantly better than the situation in other Western European countries, where output fell significantly during the interwar depression and World War II. As did the rest of Western Europe after World War II, Switzerland grew faster than trend from 1944 to 1973. The other countries, however, tended to move to new, higher balanced-growth paths in the 1970s and 1980s. As an example, in Figure 4 we plot GDP per working-age person for Italy, whose experience is fairly typical of a number of Western European countries. Italy's output fell sharply during World War II, grew faster than trend as Italy recovered from the war, and then settled into a new growth path in the 1970s. Instead of moving to a new balanced-growth path, as in Italy, Switzerland's GDP per 
Figure 4. Italy: GDP per working-age person

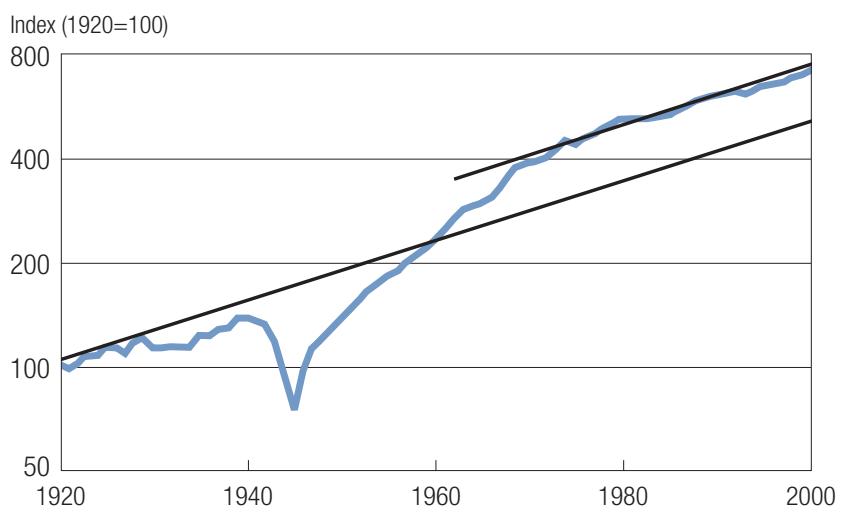

working-age person grew much slower than trend following 1973.

Figures 5 and 6 present output per working-age person for New Zealand and Switzerland over the last half century. The data are presented with the 2 percent trend removed, and the series are normalized so that GDP per working-age person is 100 in the first year of the great depression. For New Zealand, the first year of the great depression is 1974, while in Switzerland the depression starts a year earlier, in 1973. In New Zealand, output per working-age person grew on trend from 1955 to 1974, with a small deviation from trend in the late 1960s. Switzerland, however, was below trend and grew faster from 1955 to 1970 . This is not unusual, as most of Europe grew faster than the trend growth rate as it recovered from World War II. What is striking about Figures 5 and 6 is the severe and prolonged decline in trendadjusted output that the countries experienced starting in the mid-1970s. New Zealand's trend-adjusted output per working-age person fell by 21 percent from 1974 to 1984, and Switzerland's GDP declined by 19 percent over the period 1973-83. In New Zealand, output continued to fall and was only 67 percent of its trend-corrected 1974 level in 2000, and in Switzerland output was only 72 percent of its 1973 level in 2000 .

It is important to note that Figures 5 and 6 reflect an internal comparison of output growth. Both New Zealand and Switzerland had relatively high incomes per capita compared to many other countries in any given year. As measured in the Penn World Tables, Switzerland had the highest income per capita in the world in 1970 and still had one of the ten highest incomes per capita in 2000. New Zealand ranked eighth in 1970 and twenty-second out of the 133 countries for which data were available in 2000. The decline in the cross-sectional ranking is another indicator of these two countries' poor growth. 
Figure 5. New Zealand: Detrended GDP per working-age person

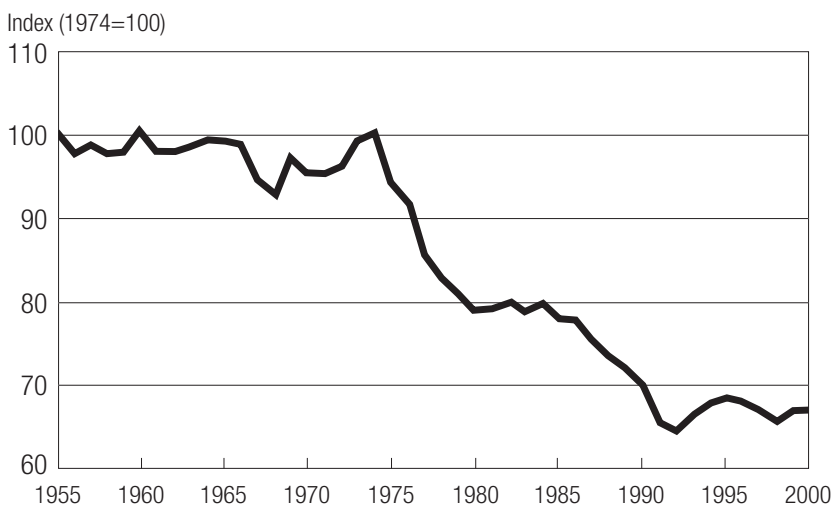

Figure 6. Switzerland: Detrended GDP per working-age person

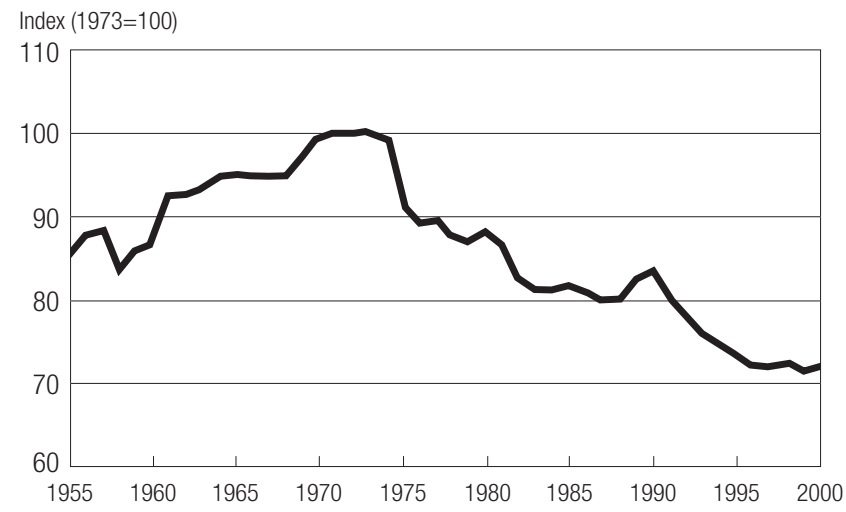

\section{Great Depression or Slow Growth?}

Some might object to our use of the term "great depression" to describe the situations in New Zealand and Switzerland. Mention of the Great Depressions in the United States and the United Kingdom during the interwar years conjures up images of breadlines and mass unemployment. The people of New Zealand and Switzerland have not experienced this kind of displacement, nor do outsiders view the countries as being depressed. Though these deviations from trend have not resulted in massive displacement or brought international scrutiny and concern, a simple comparison with Japan places 
important perspective on the seriousness of the New Zealand and Switzerland great depressions.

Kehoe-Prescott consider two characteristics important in defining a great depression. First, the deviation of output per working-age person from trend must be large, and second, the deviation from trend must occur quickly. Using the methodology outlined in the previous section, they define a period of economic growth below trend as a great depression if it meets the following three conditions:

1. There is no significant recovery during the period in the sense that there is no subperiod of a decade or longer in which the growth of output per working-age person returns to rates of 2 percent or better.

2 . There is at least one year in which output per working-age person is at least 20 percent below trend.

3. There is at least one year in the first decade of the great depression in which output per working-age person is at least 15 percent below trend.

It is clear from Figures 5 and 6 that the economic performances of New Zealand over the period 1974-2000 and Switzerland over the period 1973-2000 meet these criteria.

The small economies of New Zealand and Switzerland, as well as their relative importance in the world economy, have kept much of the international attention away from their poor growth. To appreciate the importance of this, we need only look to Japan. Detrended output per working-age person in Japan has fallen by about 9 percent over the period 1991-2002 and continues to fall. ${ }^{3}$ Figure 7 displays detrended output per working-age person for Japan.

Figure 7. Japan: Detrended GDP per working-age person

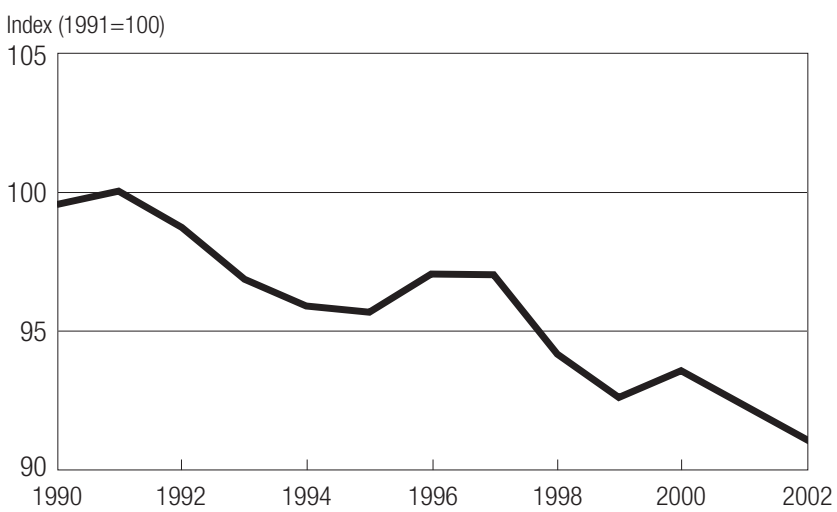


When we compare Figure 7 to Figures 5 and 6 , it is obvious that the current depression in Japan is milder than were the first decades of the depressions in New Zealand and Switzerland. Japan's importance in the world economy, however, has attracted attention to its situation. The February 16, 2002, cover of the Economist reads "The Sadness of Japan" and features a special report on Japan's troubled economy. Two weeks later, the March 3, 2002, issue of the Economist reports that "by several measures, Japan's slump is now worse than America's was in the 1930s."

Japan's economy may be headed into a great depression. Economists, policymakers, and observers agree that the lack of economic growth in Japan is a serious concern. If the economies of New Zealand and Switzerland were as large as Japan's, their situations might be as widely publicized and fretted over. People know that Japan is in trouble, and not just experiencing slow growth. Compared to Japan, the periods 1974-2000 in New Zealand and 1973-2000 in Switzerland were worse and were, indeed, great depressions.

Whether or not these countries are still in great depressions remains to be seen. From 1992 to 2002, New Zealand managed to grow at or above the trend growth rate. If growth continues to beat the trend rate, New Zealand may be returning to its previous balanced-growth path. We cannot, however, rule out the possibility that New Zealand may continue to grow about 2 percent per year and is settling into a new, lower balanced-growth path. For Switzerland, the return to the trend growth rate appears to happen about 1996. From 1996 to 2000, GDP per working-age person grew at a little less than 2 percent per year on average. Again, it could be Switzerland settling into a new, lower balanced-growth path. We simply do not have enough data, however, to determine whether or not these countries are continuing onto lower balanced-growth paths. Only time can answer this question, and we focus our attention on the period 1974-92 for New Zealand and 1973-96 for Switzerland, periods in which we know the two countries were in great depressions.

\section{Growth Accounting}

To evaluate the contributions of various factors to the changes in output per working-age person, we set up an accounting framework based on the neoclassical growth model. For a more detailed discussion of the foundations and motivation for the particular functional forms and a thorough analysis, see the work of Kehoe-Prescott and Prescott (2002).

As explained earlier, we model aggregate production using the CobbDouglas form. Since we are concerned with growth in output per working-age person relative to a balanced-growth path, it is useful to write the production 
function in terms of output per working-age person and measures of factor inputs that are constant along a balanced-growth path:

$$
\frac{Y_{t}}{N_{t}}=A_{t}^{\frac{1}{1-\alpha}}\left(\frac{K_{t}}{Y_{t}}\right)^{\frac{a}{1-\alpha}} \frac{L_{t}}{N_{t}},
$$

where $Y_{t}$ is output, $K_{t}$ is capital, $L_{t}$ is labor, $N_{t}$ is working-age population, and $A_{t}$ is TFP. TFP is calculated as the residual after accounting for capital and labor:

$$
A_{t}=Y_{t} / K_{t}^{\alpha} L_{t}^{1-\alpha}
$$

To compute the $A_{t}$ series for New Zealand and Switzerland, we compile data on output, labor, and investment from each country's national accounts. Labor is measured as total hours worked. We construct $L_{t}$ by multiplying the country's average yearly employment by the average number of hours worked per week. Using investment data, we generate the series of capital stocks using

$$
K_{t+1}=(1-\delta) K_{t}+X_{t}
$$

where $X_{t}$ is investment (measured as changes in inventories and gross fixed capital formation) and $\delta$ is the depreciation rate. Given a value for $\delta$, we choose the initial capital stock so that the capital-output ratio is the same in 1955 as its average over the period $1955-60$. We set $\delta=0.05$, which implies that capital consumption as a fraction of output, $\delta K_{t} / Y_{t}$, is 0.139 for New Zealand and 0.164 for Switzerland; in the data, these ratios are 0.166 and 0.167 , respectively. When we choose $\delta$ to match the depreciation output ratio in the two countries, we find $\delta=0.081$ for New Zealand and $\delta=0.049$ for Switzerland. We choose to use 0.05 in our baseline calibration so that technological parameters are identical across countries and because a depreciation rate of 0.081 in New Zealand implies a capital-output ratio that is much smaller than that found in comparable countries.

We still need to choose a value for capital's share of income, $\alpha$. Unfortunately, neither New Zealand nor Switzerland publishes data detailed enough to compute labor and capital shares as in the work of Cooley and Prescott (1995) or Gollin (2002). These methods require, at a minimum, information on the operating surplus of private unincorporated enterprises. When we compute the crude labor share of income $(1-\alpha)$ that does not account for the self-employed, we find values that imply $\alpha$ around 0.47 and 0.48 for 
New Zealand and Switzerland, respectively. ${ }^{4}$ Gollin (2002) shows that factor shares adjusted for self-employment income and sectoral composition are remarkably constant across both time and countries, however, and that the capital shares cluster around 0.30. Given the evidence presented in Gollin (2002) and our crude calculation of factor shares, we choose to set capital's share of income, $\alpha$, to 0.35 for both countries. ${ }^{5}$

As well as reporting the growth accounting and model results using our baseline parameterization, we also report the results using the $\delta$ and $\alpha$ values taken from New Zealand and Switzerland's data. We report these in Tables 1 and 2 under the heading "Alternative calibration." As can be seen from these tables, our choice of values for $\delta$ and $\alpha$ has no qualitative effect on our results, and very little quantitative difference.

Table 1. Growth accounting in New Zealand: Decomposition of average annual changes in real GDP per working-age person (\%)

\begin{tabular}{|c|c|c|c|c|}
\hline & \multicolumn{2}{|c|}{$\begin{array}{l}\text { Benchmark calibration } \\
\alpha=0.350, \delta=0.050\end{array}$} & \multicolumn{2}{|c|}{$\begin{array}{l}\text { Alternative calibration } \\
\alpha=0.466, \delta=0.081\end{array}$} \\
\hline & Data & Model & Data & Mode \\
\hline \multicolumn{5}{|l|}{$1974-80$} \\
\hline Change in $Y / N$ & -2.01 & -4.49 & -2.01 & -4.18 \\
\hline Due to TFP component & -4.19 & -4.19 & -5.55 & -5.55 \\
\hline Due to $K / Y$ & 2.41 & 3.21 & 3.78 & 3.84 \\
\hline Due to $L / N$ & -0.24 & -3.51 & -0.24 & -2.47 \\
\hline \multicolumn{5}{|l|}{ 1980-92 } \\
\hline Change in $Y / N$ & 0.29 & 1.67 & 0.29 & 1.48 \\
\hline Due to TFP component & 1.83 & 1.83 & 2.19 & 2.19 \\
\hline Due to $K / Y$ & 0.12 & -0.79 & -0.23 & -1.21 \\
\hline Due to $L / N$ & -1.67 & 0.63 & -1.67 & 0.50 \\
\hline \multicolumn{5}{|l|}{ 1992-2000 } \\
\hline Change in $Y / N$ & 2.46 & 2.83 & 2.46 & 3.22 \\
\hline Due to TFP component & 2.55 & 2.55 & 3.29 & 3.29 \\
\hline Due to $K / Y$ & -1.04 & -0.49 & -1.78 & -0.60 \\
\hline Due to $L / N$ & 0.95 & 0.78 & 0.95 & 0.53 \\
\hline \multicolumn{5}{|l|}{ 1974-2000 } \\
\hline Change in $Y / N$ & 0.42 & 0.61 & 0.42 & 0.71 \\
\hline Due to TFP component & 0.66 & 0.66 & 0.74 & 0.74 \\
\hline Due to $K / Y$ & 0.29 & 0.22 & 0.22 & 0.14 \\
\hline Due to $L / N$ & -0.53 & -0.28 & -0.53 & -0.18 \\
\hline
\end{tabular}


Table 2. Growth accounting in Switzerland:

Decomposition of average annual changes

in real GDP per working-age person (\%)

\begin{tabular}{|c|c|c|c|c|}
\hline & \multicolumn{2}{|c|}{$\begin{array}{l}\text { Benchmark calibration } \\
\alpha=0.350, \delta=0.050\end{array}$} & \multicolumn{2}{|c|}{$\begin{array}{l}\text { Alternative calibration } \\
\alpha=0.480, \delta=0.049\end{array}$} \\
\hline & Data & Model & Data & Model \\
\hline \multicolumn{5}{|l|}{$1973-96$} \\
\hline Change in $Y / N$ & 0.55 & 0.38 & 0.55 & 0.36 \\
\hline Due to TFP component & 0.48 & 0.48 & 0.23 & 0.23 \\
\hline Due to $K / Y$ & 0.33 & 0.44 & 0.58 & 0.53 \\
\hline Due to $L / N$ & -0.26 & -0.54 & -0.26 & -0.40 \\
\hline \multicolumn{5}{|l|}{ 1996-2000 } \\
\hline Change in $Y / N$ & 2.02 & 2.27 & 2.02 & 2.48 \\
\hline Due to TFP component & 3.03 & 3.03 & 3.70 & 3.70 \\
\hline Due to $K / Y$ & -0.96 & -1.23 & -1.63 & -1.87 \\
\hline Due to $L / N$ & -0.05 & 0.47 & -0.05 & 0.65 \\
\hline \multicolumn{5}{|l|}{$1973-2000$} \\
\hline Change in $Y / N$ & 0.77 & 0.66 & 0.77 & 0.67 \\
\hline Due to TFP component & 0.86 & 0.86 & 0.74 & 0.74 \\
\hline Due to $K / Y$ & 0.14 & 0.19 & 0.25 & 0.18 \\
\hline Due to $L / N$ & -0.23 & -0.39 & -0.23 & -0.25 \\
\hline
\end{tabular}

Using the series for labor, output, and the constructed capital stocks, we compute TFP for each of the countries. In the balanced-growth path, hours worked per working-age person are constant, and output and capital both grow at the same constant rate. It is then easy to see from equation (2) that in a balanced-growth path in which output per working-age person grows at 2 percent per year, the TFP component of output, $A_{t}^{1 / 1-\alpha}$, must also grow at 2 percent per year. Thus, we detrend the TFP component by 2 percent per year. Throughout this section and the next, we concentrate on the TFP component, $A_{t}^{1 / 1-\alpha}$, but it should not be confused with the level of TFP, $A_{t}$.

Figures 8 and 9 plot GDP per working-age person and the TFP component for New Zealand and Switzerland. A striking feature of both figures is the similarity of the TFP component and GDP per working-age person. In fact, the simple correlation coefficient for the TFP component and GDP per workingage person over the period 1970-2000 is 0.93 for New Zealand and 0.98 for Switzerland. This simple statistic suggests that TFP has played an important role in determining the growth in output in these countries.

To quantify the contributions of the TFP component and other factors in 
Great Depressions: New Zealand and Switzerland

Figure 8. New Zealand: Detrended GDP/N and TFP component

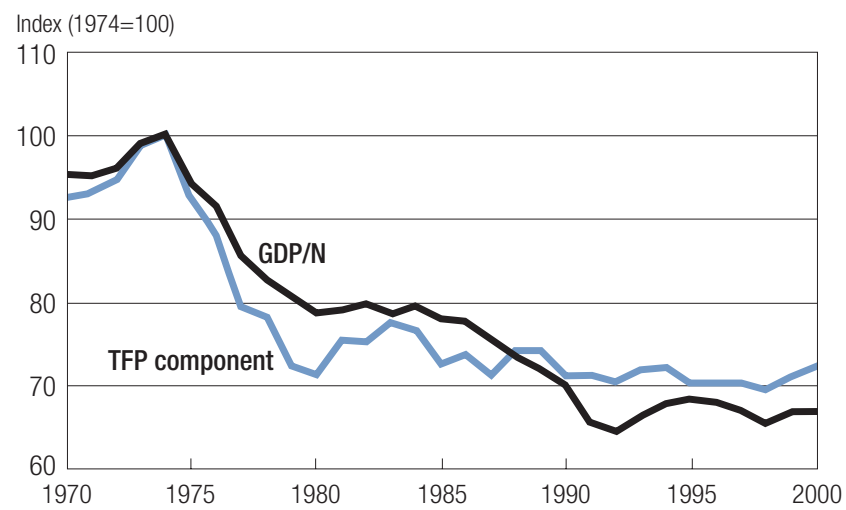

Figure 9. Switzerland: Detrended GDP/N and TFP component

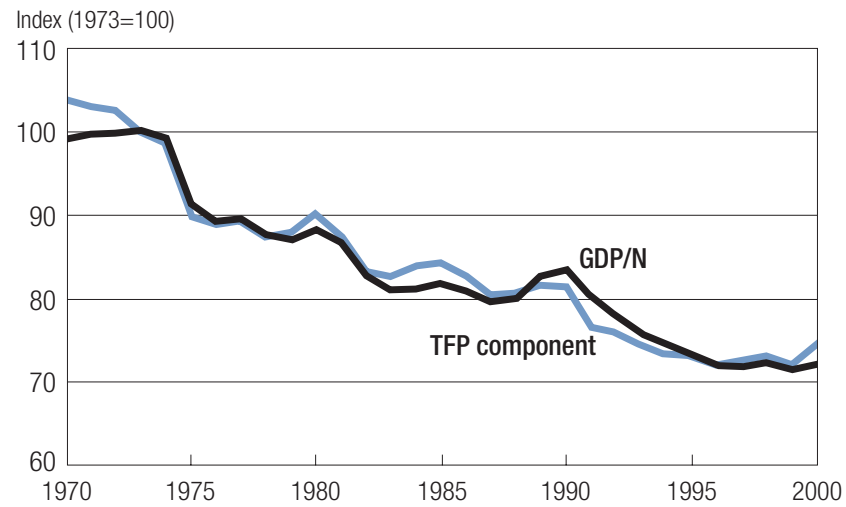

the growth of these two economies, we use our theoretical framework to guide our growth accounting. As in the work of Hayashi-Prescott, we can take logarithms of the production function (1) and rearrange terms to relate output per working-age person, hours worked per working-age person, the TFP component, and the capital-output ratio:

(5) $\log \left(\frac{Y_{t}}{N_{t}}\right)=\frac{1}{1-\alpha} \log \left(A_{t}\right)+\frac{\alpha}{1-\alpha} \log \left(\frac{K_{t}}{Y_{t}}\right)+\log \left(\frac{L_{t}}{N_{t}}\right)$. 
This expression can be used to decompose the average annual growth rate of output per working-age person over a number of years, $s$, into

$$
\begin{aligned}
& \frac{\log \left(Y_{t+s} / N_{t+s}\right)-\log \left(Y_{t} / N_{t}\right)}{s}=\frac{1}{1-\alpha}\left[\frac{\log \left(A_{t+s}\right)-\log \left(A_{t}\right)}{s}\right] \\
& +\frac{\alpha}{1-\alpha}\left[\frac{\log \left(K_{t+s} / Y_{t+s}\right)-\log \left(K_{t} / Y_{t}\right)}{s}\right] \\
& +\left[\frac{\log \left(L_{t+s} / N_{t+s}\right)-\log \left(L_{t} / N_{t}\right)}{s}\right] .
\end{aligned}
$$

The above expression decomposes changes in output per working-age person into changes in the TFP component (the first term on the right side), changes in the capital-output ratio (the second term on the right side), and changes in hours worked per working-age person (the last term on the right side). Along the balanced-growth path, both hours per worker and the capital-output ratio are constant, so we would expect these terms in (6) to be very small in our growth accounting if the economy is on the balanced-growth path.

We present the results of this decomposition for New Zealand in the first column of Table 1. In the period 1974-80, output per working-age person declined by 2.01 percent per year. ${ }^{6}$ The TFP component fell by 4.19 percent per year over this period but was offset by the capital-output ratio, which grew at 2.41 percent. From 1980 to 1992, GDP growth was well below the trend growth rate, averaging only 0.29 percent per year. Over this same period, the TFP component grew near its trend growth rate, averaging 1.83 percent per year. Large declines in labor input over this period contributed to the low GDP growth, however. From 1992 on, both the TFP component and GDP per working-age person grew at rates slightly above their trend growth rates. In this period, labor grew substantially, mostly offsetting the decreases from the earlier period.

The growth accounting for Switzerland, shown in Table 2, attributes even more of the change in GDP per working-age person to the TFP component. In the period 1973-96, output per working-age person grew at only 0.55 percent per year, and changes in the TFP component accounted for most of this, increasing by 0.48 percent per year over the same period. In this period there were only small movements in the labor input and the capital-output ratio. As has New Zealand, Switzerland has managed to increase its growth recently. Over the period 1996-2000, GDP per working-age person has grown at approximately 2.02 percent per year, which is mostly accounted for by a 3.03 percent growth rate in the TFP component. In this period the 
capital-output ratio's contribution to output growth was negative, as in New Zealand, and labor input was roughly constant.

The growth accounting confirms our intuition gained from the plots of the TFP component and output. Output growth in New Zealand and Switzerland seems to be largely accounted for by changes in the TFP component. The contributions of labor and capital are not trivial, however, particularly the contributions of labor in New Zealand. In the next section we construct a model to explore the extent to which exogenous productivity changes can account for the findings of this section.

\section{Baseline Model}

We calibrate a simple dynamic general equilibrium model to see how much of the change in output we can account for using only productivity changes. In this model agents live in a closed economy and have perfect foresight over the sequence of productivity. The model features a representative agent who chooses consumption, $C_{t}$, and labor effort, $L_{t}$, in each period to maximize

$$
\sum_{t=1970}^{\infty} \beta^{t}\left[\gamma \log \left(C_{t}\right)+(1-\gamma) \log \left(\bar{h} N_{t}-L_{t}\right)\right]
$$

subject to a sequence of budget constraints,

$$
C_{t}+K_{t+1}=w_{t} L_{t}+\left(1+r_{t}-\delta\right) K_{t},
$$

and has an initial stock of capital, $\bar{K}_{1970}$. The total number of hours available for work is $\bar{h} N_{t}$, where $N_{t}$ is the working-age population and $\bar{h}$ is the number of hours available for market work per week. We choose $\bar{h}$ to be 100. To be consistent with our growth accounting, the production technology in the economy is of the Cobb-Douglas form, implying the following feasibility constraint:

$$
C_{t}+K_{t+1}=A_{t} K_{t}^{\alpha} L_{t}^{1-\alpha}+(1-\delta) K_{t} .
$$

The utility function's parameters $\beta$ and $\gamma$ must be calibrated before solving the model. From the producer's problem, we have the standard expressions for wages, $w$, and capital rental rates, $r$,

$$
w_{t}=(1-\alpha) A_{t} K_{t}^{\alpha} L_{t}^{-\alpha} \quad r_{t}=\alpha A_{t} K_{t}^{\alpha-1} L_{t}^{1-\alpha}
$$

which allows us to use the consumer's first-order conditions to compute $\beta$ and $\gamma$ as 
(11) $\beta=\frac{C_{t}}{C_{t+1}\left(1+r_{t}-\delta\right)}$

$$
\gamma=\frac{C_{t}}{C_{t}+w_{t}\left(\bar{h} N_{t}-L_{t}\right)}
$$

where $\alpha=0.350$ and $\delta=0.050$ as in our growth accounting. We use data on consumption, capital, hours worked, and working-age population from 1955 to 1970 to compute values for $\beta$ and $\gamma$ for each year. We then take averages over this period and obtain $\beta=0.961$ and $\gamma=0.275$ for New Zealand, and $\beta=0.984$ and $\gamma=0.357$ for Switzerland. It is worth pointing out that the high calibrated value of $\gamma$ for Switzerland compared to that for New Zealand reflects the fact that the average working-age person in Switzerland worked much more over the period 1954-70 than did the average working-age person in New Zealand. As Lambelet and Mihailov (2000) stress, the level of hours worked per working-age person is high in Switzerland compared to its levels in many other industrialized countries.

It should be pointed out that the real investment series used to calculate the capital stock in (4) and to calibrate the discount factor $\beta$ using the consumption-investment trade-off in (11) is formed by deflating nominal investment by the GDP deflator rather than by the investment deflator. This decision makes a lot of sense when we are thinking in terms of the labor leisure trade-off (11). It makes less sense when we are thinking in terms of capital accumulation (4). An alternative formulation worth exploring would replace the feasibility condition (9) with

$$
\begin{aligned}
& \text { (13) } C_{t}+q_{t} X_{t}=A_{t} K_{t}^{\alpha} L_{t}^{1-\alpha}+(1-\delta) K_{t} . \\
& \text { (14) } K_{t+1}=(1-\delta) K_{t}+X_{t} .
\end{aligned}
$$

Here $q_{t}$ is the price of the investment good, measured as the ratio of the investment deflator to a deflator for the rest of GDP. In this framework, some of technological progress shows up in increases in TFP and some in a fall in the relative price of investment.

Given the values for the parameters, the initial capital stock, and series for $N_{t}$ and $A_{t}$, we solve the model for New Zealand and Switzerland over 1970-2009. For 1970-2000 the values of $A_{t}$ and $N_{t}$ are exactly those from the data, and we set the initial capital stock to its 1970 value. For 2001-9, we assume TFP grows at the same average rate at which it grew from 1954 to 1970 and that the population grows at the same rate it did between 1999 and 2000. We impose the terminal condition that the equilibrium of the model 
converges to a balanced-growth path by 2009 .

Figures 10 and 11 (see following pages) display the results of numerical experiments of the model for New Zealand and Switzerland. For both New Zealand and Switzerland, the model does a good job of accounting for the falling output per working-age person. For New Zealand, detrended output per working-age person fell by 36 percent from 1974 to 1992, whereas the model's output falls 35 percent over the same period. The model captures the changes in the capital-output ratio as well. The model does not generate the large change in labor we see in the late 1980s and early 1990s. Beginning in 1987, the number of hours worked per week per working-age person decreased steadily from twenty-four to twenty in 1991. Following 1991, hours worked increased sharply and have remained between twenty-two and twenty-three hours per week. These movements in hours worked are most likely the result of the extensive labor market and welfare reforms that were implemented throughout the early 1990s. Our model does not take these large policy changes into account.

The model reproduces the features of the Swiss data well. The model's output per working-age person falls by 31 percent from 1973 to 1996, compared with 28 percent in the data. The model also does an impressive job of tracking the capital-output ratio. Changes in the model's hours-worked series also match the data fairly well, although the levels are too high, and this accounts for most of the deviations between the model's GDP from that in the data. Over the period 1970-2000, working-age persons in Switzerland worked fewer hours than they had during the period 1955-70, to which we have calibrated the parameter $\gamma$ that is crucial in governing the labor-leisure trade-off.

In the second columns of Tables 1 and 2 we display the results of our growth accounting on the model's labor, capital, and output series. A comparison of the first and second columns in Table 1 confirms the model's ability to generate the features of the New Zealand data. The differences between the model results and the data are largely accounted for by differences in labor input: the data have a smaller drop in hours worked over the period 1974-80 than does the model, but the data have another drop, rather than a small increase, over 1980-92. Growth accounting in the Swiss model is even more striking. A simple growth model augmented with TFP shocks not only captures the changes in output but also does a good job of matching the contributions of labor and capital to output growth.

\section{Explaining TFP}

Our growth accounting makes it clear that understanding the economic performance of New Zealand and Switzerland requires an understanding of TFP. In attempting to account for cross-country levels of income per capita, 
Figure 10. New Zealand: Results of numerical experiments of the model: (a) Y/N, (b) K/Y, (c) L/N
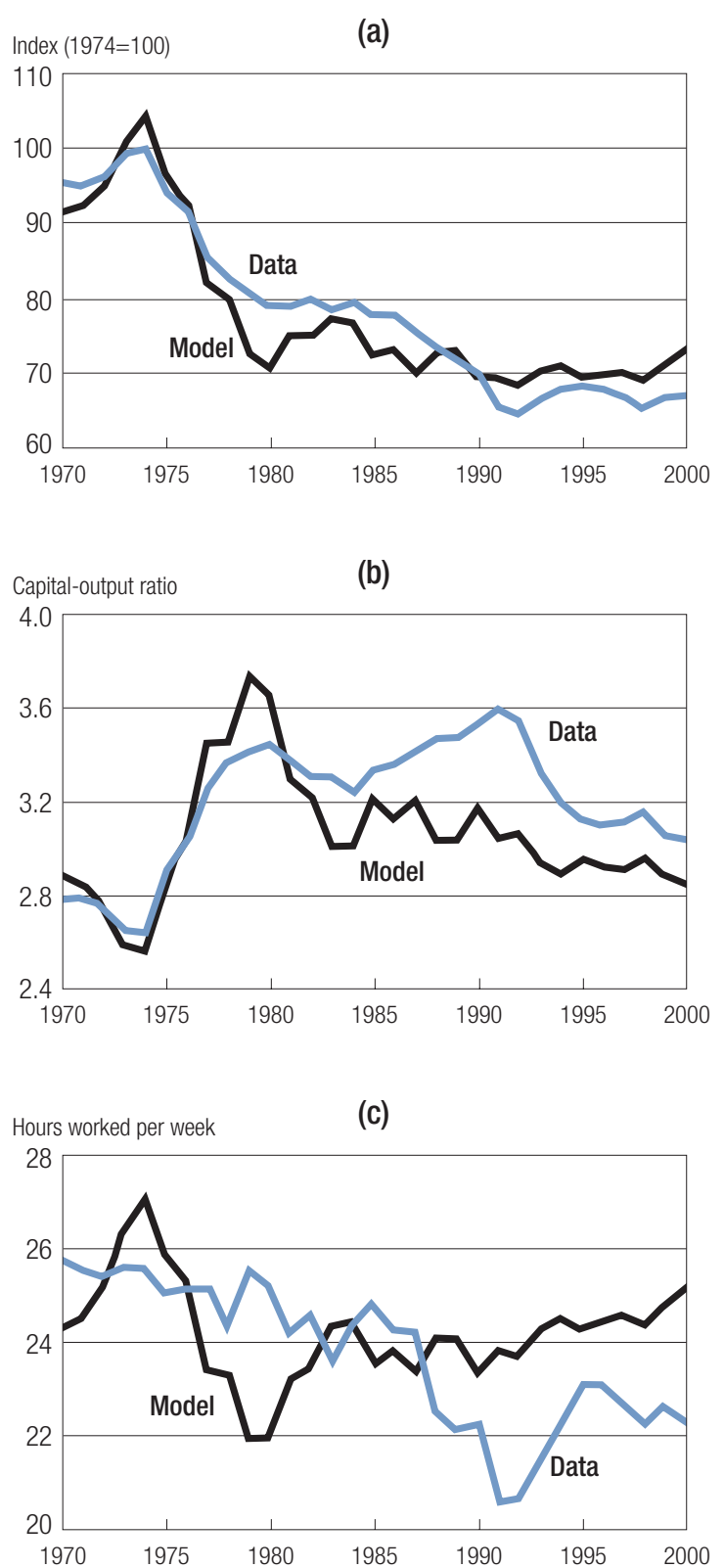
Great Depressions: New Zealand and Switzerland

Figure 11. Switzerland: Results of numerical experiments of the model: $(a) \mathrm{Y} / \mathrm{N},(b) \mathrm{K} / \mathrm{Y},(c) \mathrm{L} / \mathrm{N}$
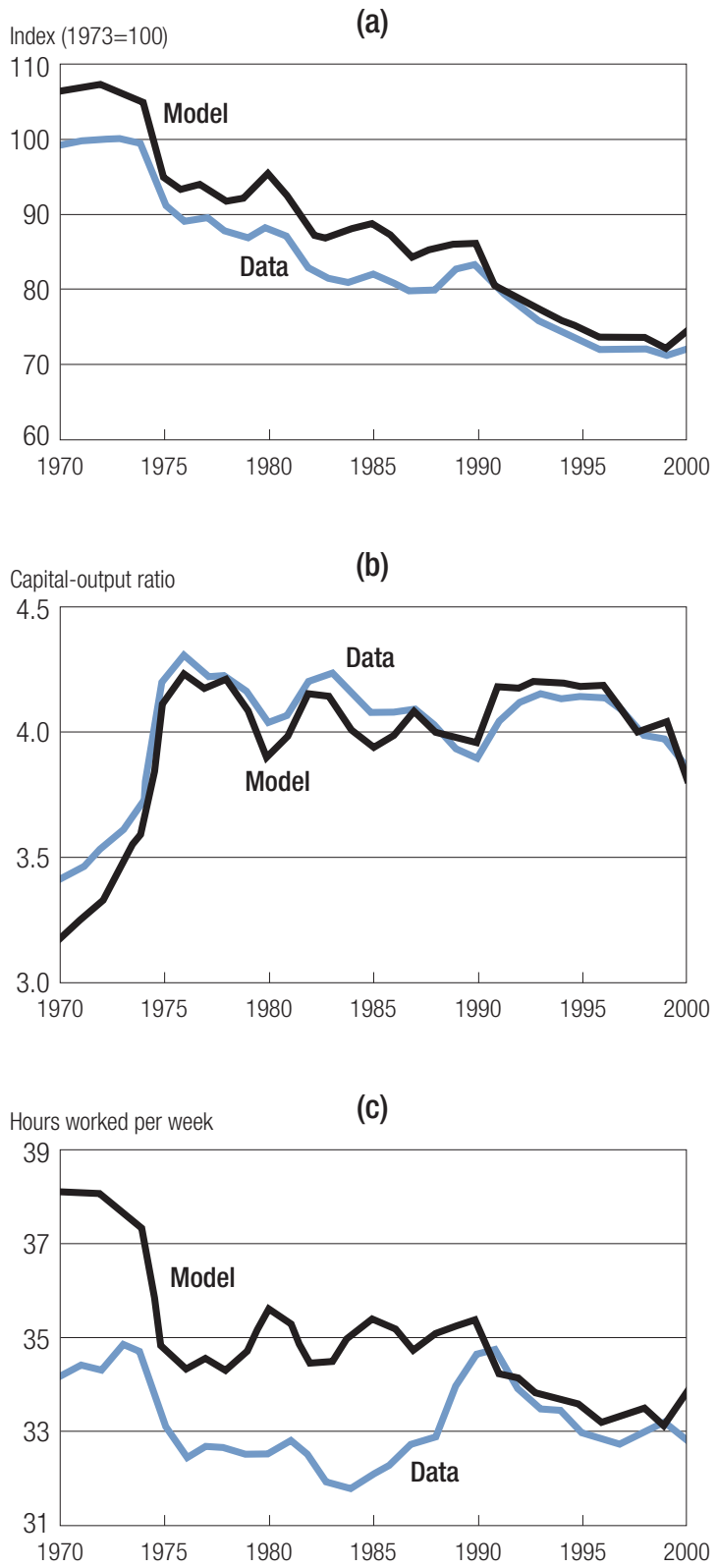
Prescott (1998) concludes that only TFP, and not the accumulation of capital or the labor input, can account for these differences. Thus, to explain both the cross-country distribution of per capita income and the large movements of GDP within a specific country, we need to be able to explain TFP. Prescott (1998) calls for a theory of TFP and suggests that a candidate theory might involve a country's resistance to the adoption of more efficient technologies. This theory is further developed in the work of Parente and Prescott (2002), in which monopoly rights to work practices are considered as an institution that slows the adoption of new technologies.

While there is no broadly accepted theory of TFP, a country's institutions likely play a large role in the evolution of its TFP. Institutions that may be important include a country's openness to foreign competition, the existence of monopoly rights, the prevalence of labor unions, government regulation of industry, and price controls, among others. In this section we discuss some of the institutions in New Zealand and Switzerland that are worth investigating. In particular, we are searching for changes in the institutional structure in these countries that took place around the beginning of their depressions and have persisted throughout the period. Temporary "shocks" will not be able to account for the prolonged depressions, since neither of these countries has recovered to its trend TFP and output levels.

\section{New Zealand}

Given New Zealand's poor economic performance after 1974, it should come as no surprise that other researchers have studied the determinants of economic growth there. Hall (1996) does aggregate growth accounting for New Zealand based on detailed sectoral calculations. Like us, he finds that TFP is the dominant source of fluctuations in real GDP. A number of researchers focus on the role of government intervention in determining productivity. (See Dalziel and Lattimore 2001 and Silverstone, Bollard, and Lattimore 1996.) During the period 1978-84, the government made large investments, later judged to have been unproductive, as part of the "Think Big" strategy. The period 1984-92 was characterized by massive economic reforms, which have been characterized by some as ill-sequenced.

\section{Foreign Trade}

Here we consider the effects of external shocks on the New Zealand economy. New Zealand's trade (imports plus exports) as a percentage of GDP averaged 56 percent for the period 1972-80, larger than that in Australia, the United Kingdom, or Canada. Since New Zealand is a small open economy, changes in the terms of trade or in trade policy from outside the country can have significant effects and are frequently cited as a determinant of growth 
in New Zealand. As Briggs (2003) stresses, New Zealand's foreign trade has grown much more slowly since 1970 than has trade in the rest of the industrialized world.

We choose to define the terms of trade as the price of a country's exports relative to the price of the country's imports. Easterly et al. (1993) present evidence that terms-of-trade shocks can explain a substantial amount of the variance in GDP growth rates in time series regressions. Working in the same neoclassical methodology as this study, Perri-Quadrini attribute a large portion of Italy's depression in the 1930s to a combination of increasing trade barriers and rigid wages. Grimes (1991) finds that the reduction in New Zealand's terms of trade over the period 1950-85 was responsible for a reduction in the annual GDP growth rate of 0.13 percent.

Our measure of the terms of trade is constructed using the implicit price deflator for exports and imports from the national accounts. Assume that the prevailing ratio of the world price for the goods that New Zealand exports to the price of the goods that New Zealand imports is $p_{t}$ and that the rest of the world levies an ad valorem tariff of $\tau_{t}^{*}$ on New Zealand's exports. Arbitrage implies that the price received by New Zealand exporters for their goods is $p_{t} /\left(1+\tau_{t}^{*}\right)$. Since the implicit price deflator for New Zealand imports measures market prices, it includes any tariffs paid on imports. Let $\tau_{t}$ be the ad valorem tariff on imports into New Zealand. Consequently, our measure of the terms of trade (ToT) can be written

$$
T o T_{t}=\frac{p_{t}}{\left(1+\tau_{t}\right)\left(1+\tau_{t}^{*}\right)}
$$

We plot New Zealand's terms of trade in Figure 12. New Zealand's termsof-trade level falls to 85 percent of its 1974 level in 1975 and stays low until 1985 , when it starts to return to roughly its pre-1974 average. It is significant that the sharp drop in New Zealand's terms of trade coincided with both the beginning of New Zealand's great depression and the accession of the United Kingdom to the EEC. It is, of course, true that the sharp drop in New Zealand's terms of trade from 1973 to 1975 coincided with the first oil shock, but much of the persistence of the terms-of-trade movements after 1970 can be explained by trade policy. The improvements in the terms of trade in the late 1980s, for example, coincided with significant trade liberalization (Evans et al. 1996).

Following Belich $(1996,2001)$ we can divide New Zealand's recent trade history into two periods, recolonization and decolonization. Recolonization describes the period 1880-1970, in which the trade between New Zealand and the United Kingdom closely resembled that of a colony providing primary 
Figure 12. New Zealand: Price of exports / price of imports

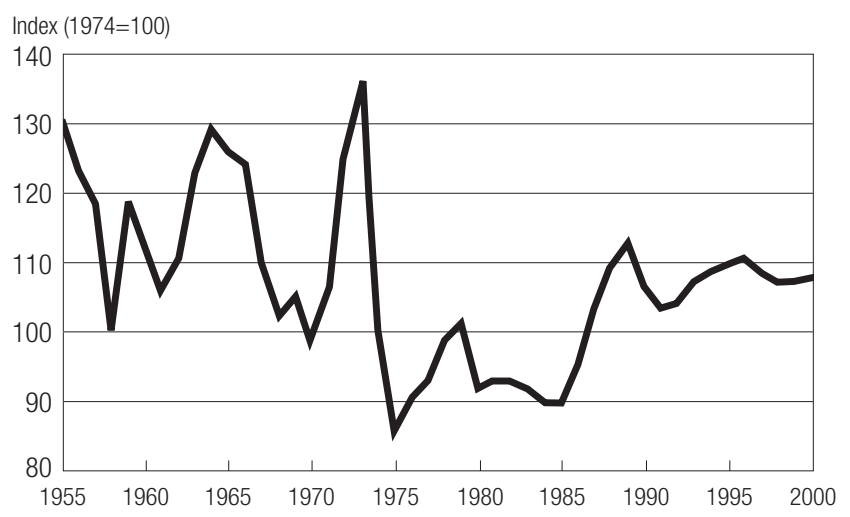

materials to its mother country. As a colonial farm, New Zealand's trade relations in this period were characterized by preferential trade arrangements between the United Kingdom and the Dominions. This relationship was key to New Zealand's economy. New Zealand exported wool, dairy, and pastoral products to the United Kingdom and imported manufactures, fuels, and capital goods. The bulk purchase agreements between the United Kingdom and New Zealand guaranteed a market for New Zealand exports during and following World War II, and restrictions on imports of other products into the United Kingdom further protected New Zealand's trade.

Decolonization began in 1970 and continues today, as New Zealand competes in a world market without preferential U.K. relations. The 1960s ushered in a new era of New Zealand-United Kingdom trade policy. Beginning in 1960, New Zealand lowered the preference on U.K. imports and continued to do so until the U.K. tariff preference was phased out in 1977 (Lattimore and Wooding 1996). These changes were partially in response to the more drastic changes in policy being undertaken in the United Kingdom. In 1968, the EEC implemented a customs union that eliminated duties between member countries, and imposed a common external tariff. Five years later, New Zealand's largest and most accessible trading partner erected major trading barriers when the United Kingdom joined the EEC in 1973. Though New Zealand retained some special access under bilateral agreements with the EEC, this change in policy led to a drastic change in New Zealand's trading pattern. New Zealand's external trade was further jeopardized by the EEC in third markets. New Zealand's agricultural products now had to compete with the heavily subsidized agricultural exports of Europe. Even 
in the United Kingdom, where New Zealand still enjoyed some privilege, exporters now had to compete with subsidized U.K. farmers (Hawke and Lattimore 1999).

Evidence of the impact of these barriers is visible in Figures 13 and 14. Figure 13 shows the share of New Zealand's total exports and imports sourced from the United Kingdom. The figure shows the dramatic decline in the United Kingdom's share of New Zealand's imports and exports throughout the 1960s and 1970s. Even though this share falls throughout the 1960s, there is a sharp decrease from 1972 to 1974 as New Zealand dealt with the increased trade barriers. Figure 14 reveals an important detail of this trade

Figure 13. United Kingdom's share of New Zealand trade

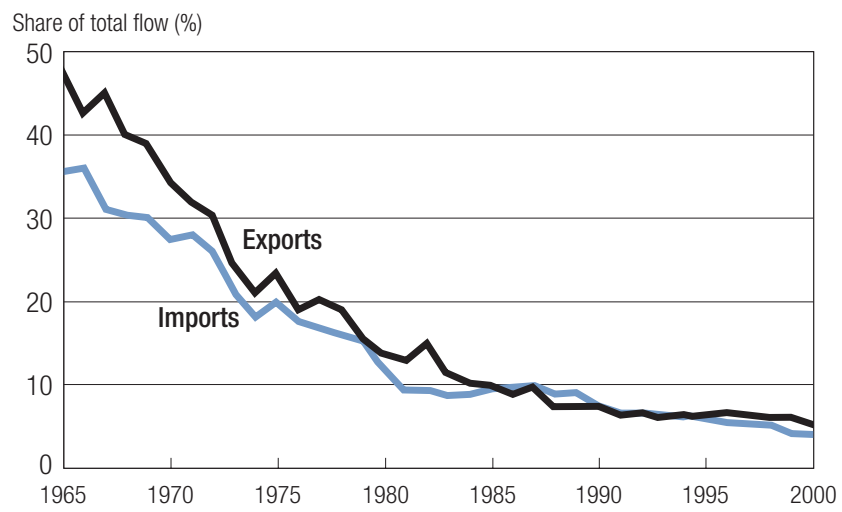

Figure 14. United Kingdom's share of imported capital goods

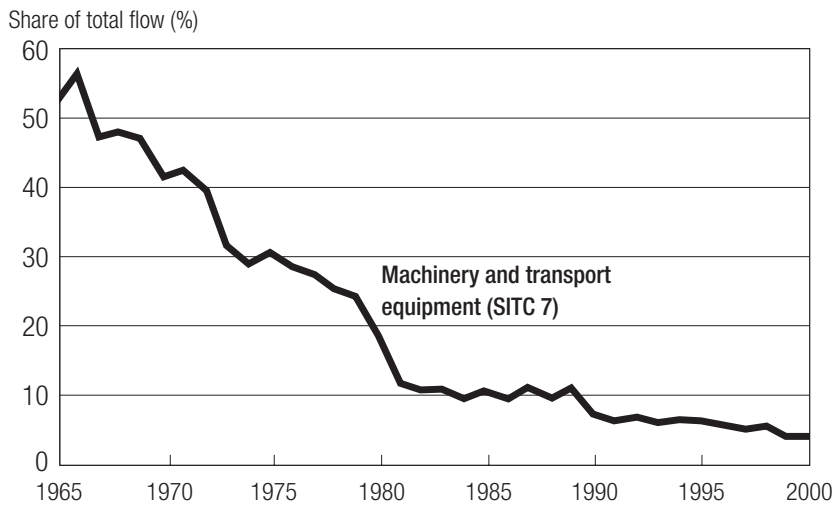


pattern. New Zealand sourced more than half of its imported machinery and transport goods from the United Kingdom in 1965, compared to approximately 4 percent in 2000 .

The changes in New Zealand's trade patterns are certainly not entirely driven by the EEC customs union. New Zealand's protection policies were complex and changing throughout the pre-reform era. Besides tariffs, the New Zealand government used import licensing, export incentives, and exchange controls to protect local industry and stimulate growth. Growth and development in Asia is also likely to have had a strong effect on New Zealand's trade patterns. Goods from Asia have replaced the imported capital goods previously sourced from Europe almost percent-for-percent. It is unlikely, however, that New Zealand faced trade policies in Asia that were as accommodating as those from the pre-EEC United Kingdom.

The changes in the terms of trade and the changes in New Zealand's relationships with its trade partners - and the resulting disruption in trade patterns - undoubtedly had a major impact on the New Zealand economy. The results of our numerical experiments in the previous section indicate that, to assign significant blame to these external shocks as a cause of New Zealand's great depression, we need to be able to construct a model in which the impact of these shocks shows up in measured TFP. An obvious direction to take in modeling the impact of changes in the terms of trade and trade policy would be to model imported goods as intermediates in production, as done by Amaral-MacGee and Perri-Quadrini. A sharp drop in the terms of trade and/or an increase in trade barriers can lead to a large decrease in consumption and investment. As stressed by Kohli (2004), however, this sort of shock will have a much smaller effect on real GDP because imports are deflated by an import price deflator and then subtracted from consumption, investment, government spending, and exports to form real GDP. Consequently, the simple approach that has trade shocks affecting production by making foreign inputs more expensive cannot account for a large drop in TFP because it has little effect on measured GDP unless labor and capital inputs change. An alternative approach would be to model the frictions involved in moving labor and capital between the sectors that produce exportable goods and nontradable goods into the sectors that produce importable goods as in de Cordoba and Kehoe (2000).

A challenge to any theory of New Zealand's great depression based on trade shocks is the observation that the return of the terms of trade to higher levels and the trade liberalization of the late 1980s and early 1990s has not, at least so far, resulted in a return of New Zealand to its pre-1974 balancedgrowth path. 
Figure 15. Switzerland: Price of exports / price of imports

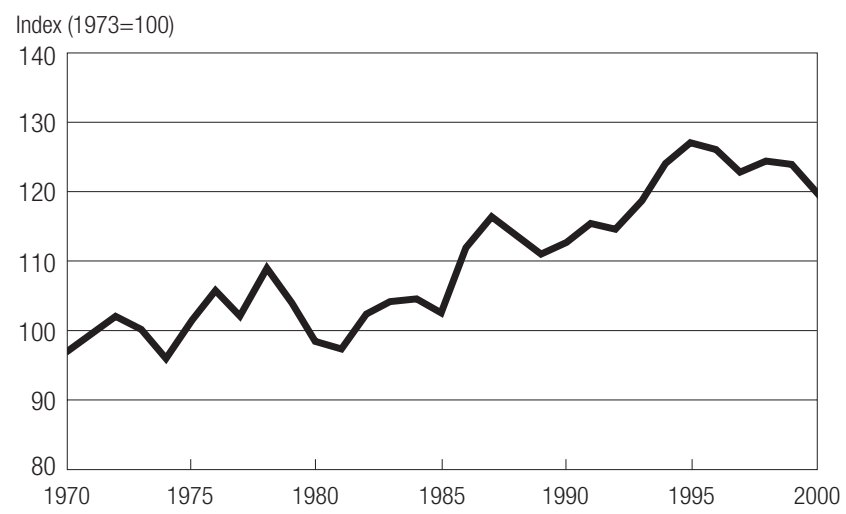

Switzerland

None of Switzerland's falling TFP can be explained by changes in the terms of trade. As shown in Figure 15, Switzerland's terms of trade have been steadily increasing over the last thirty years. Switzerland's trade patterns have stayed relatively constant over the last thirty years, indicating that there was probably not any large change in trade relations. Given the lack of evidence that Switzerland's external trade has changed drastically, we turn our attention to two other possible explanations.

\section{Structural Rigidities}

Hviding (1998) divides Switzerland's economy into two sectors, the open sector and the sheltered sector. The open sector consists of industries that compete in international markets and are not protected by Swiss trade policy. These industries include most of manufacturing. The sheltered sector is made up of the heavily protected and subsidized agricultural sector and many of the service industries such as telecommunications, information technology, and construction.

The sheltered sector's domestically oriented industries are relatively rigid, and price-fixing, market-share agreements, and explicit cartels are common. Swiss industries also enjoy a domestic market segmented by canton-specific technological standards and licensing. These rigidities may have had less of an impact on aggregate technological growth in the past, but may be coming to center stage as these protected industries experience massive technological change.

Hviding (1998) suggests that the combination of structural rigidities and sector-specific technological change has acted as a drag on Switzerland's 
output growth. In the 1950s and 1960s, much of the worldwide innovation took place in the manufacturing industries. In Switzerland, these sectors faced international competition and needed to adopt the improving technologies and work practices to stay competitive. From the 1970s onward, however, the important worldwide innovations were concentrated in sectors such as telecommunications, information technology, and biotechnology. In Switzerland these industries are part of the sheltered sector. The lack of competition in these sectors may slow the rate of adoption of more efficient technologies, thereby slowing aggregate productivity growth.

An analysis of the productivity of these two sectors would allow us to carefully evaluate this potential explanation for Switzerland's poor aggregate productivity growth. Unfortunately, we have been unable to obtain detailed data by industry, particularly data on capital, for Switzerland. Faced with this constraint, Hviding (1998) assigns manufacturing to the open sector and the nonmanufacturing private sector to the sheltered sector. Given this dichotomy, Hviding looks to labor productivity for evidence of slow productivity growth. Over the period 1965-75, the Swiss manufacturing sector's labor productivity grew at an average annual rate of 2.75 percent. In this same period, the nonmanufacturing sector's labor productivity grew at 2.5 percent per year on average. In the period 1976-96, manufacturing productivity continued its growth, averaging 2.5 percent per year. Nonmanufacturing productivity growth fell to only 0.5 percent per year during the period 1976-96, however.

The combination of structural rigidities and sector-specific technological change appears to be a plausible explanation for Switzerland's poor productivity growth. This preliminary evidence suggests that a detailed analysis of the structure of Swiss industry might yield important insights into Switzerland's great depression.

\section{Foreign Labor}

A second possible explanation for Switzerland's poor productivity growth may be the structure of its workforce. Since the early 1970s, there has been an increasing stock of permanent foreign workers in Switzerland. These workers tend to be low skilled, and between 1977 and 2000, they have more than doubled their share in unemployment. If new technology and high-skilled workers are complements, then access to a large pool of low-skilled workers may hinder the new technology's adoption.

Sheldon (2000) finds that technological change in Switzerland is skill biased and that the increasing number of low-skilled, permanent foreign workers is slowing technological change. Switzerland's foreign worker policy allows three kinds of temporary foreign work permits and a permanent permit 
that entitles the holder to the same rights as national workers. In particular, permanent permit holders may continue to live in Switzerland even when they are not employed. Since the 1960s, the fraction of foreign workers under permanent permits has increased steadily, more than doubling from 1970 to 2000. Sheldon (2001) reports that the share of permanent and annual workers in the total workforce has remained relatively constant, about 18 percent, but that the share of these workers in unemployment has increased from about 20 percent of unemployment in 1977 to more than 45 percent in 1999.

Sheldon (2000) estimates a trans-log production function for Switzerland, using a panel of twenty-one industries and five types of labor input. The panel data allow Sheldon to classify the foreign workers by their permit type. The estimations imply that Switzerland's technological change is factor saving with regard to most types of foreign workers. Sheldon (2001) couples this finding with the rising number of available low-skilled workers and suggests that firms may be substituting low-wage workers for new technologies.

The lack of productivity growth in the sheltered sector could certainly be related to the foreign worker situation. The protected sector in Switzerland encompasses many industries that are considered large employers of low-skilled labor. These industries include agriculture, restaurants, hotels, and other service industries. The combination of a relatively uncompetitive environment and a large supply of low-skilled workers may be important in explaining the recent performance of the Swiss economy.

\section{Quality of Data}

Recent work by Abrahamsen et al. (2003) argues that our finding that Switzerland has gone though a great depression is partially the result of the poor quality of Swiss data and that, given this problem with the data, it is difficult or impossible to compare Swiss economic performance with that of other countries, like the United States. To start with, Abrahamsen et al. ignore Swiss data for the period before 1980, presumably because they believe that these data are so bad that they have to be discarded completely. Notice that, in Figure 6, the sharpest drop in GDP per working-age person in Switzerland occurred in 1973-80. As discussed in Kehoe and Ruhl (2005), the techniques employed here for splicing together data from different systems of accounts are the same as those used by the International Monetary Fund and the Organisation for Economic Co-operation and Development.

Abrahamsen et al., in considering the post-1980 data, point out that, in measuring GDP the United States uses the System of National Accounts of 1993 (SNA93), while Switzerland uses the System of National Accounts of 1968 (SNA68). The SNA93 includes a sector for investment in "intangibles" that is not found in SNA68 and includes purchases of software. If either the 
rate of investment in intangibles increased or the price of intangibles relative to other goods decreased, then the SNA68-measured GDP would be lower than the SNA93-measured GDP; Abrahamsen et al. argue that this increase could be as large as 5 percent over the period 1973-2000 if Switzerland's investment in intangibles behaves as it did in the United States. Since the publication of Abrahamsen et al., Switzerland has switched to a system of accounts (the European System of Accounts of 1995) based on SNA93. Kehoe and Ruhl (2005) analyze the effects of the switch to an SNA93-based accounting system and find that the new accounting system adds 2.8 percent- $-\mathrm{a}$ little more than half of that predicted by Abrahamsen et al.- more growth over the period 1981-2001. Though the switch in accounting systems does increase the growth in GDP for Switzerland, it is far from enough to overturn our findings that Switzerland is in a great depression.

Given the arguments of Abrahamsen et al., we need to maintain some skepticism in working with Swiss data. Simply giving up on the data, however, would leave us unable to analyze the causes of the Swiss great depression.

Abrahamsen et al. also disagree with our concept of national income and depressions. Instead of using GDP per working-age population, they use output per hour worked. When we compute GDP per hour worked in Switzerland over the entire period 1973-2000, we find that GDP per hour worked in Switzerland falls by only 14 percent compared to that in the United States, while GDP per working-age person falls by 32 percent compared to that in the United States. This relative equality of labor productivity, Abrahamsen et al. claim, is an indication that Switzerland is not a depressed country. Thus, they are implicitly defining a depression as a period in which labor productivity does not grow as fast as labor productivity in the United States. Because their definition of depression would rule out periods in which drops in output are driven by massive increases in unemployment, it would probably be best for them to use another term.

Abrahamsen et al. also look for evidence of depressions using a measure much more closely related to ours. They choose to run a regression with cross-country fixed effects to study the determinants of New Zealand's and Switzerland's growth. In particular, they estimate equations of the form

$$
g(Y / L)_{i, t}=g(A)_{i, t}+\alpha g(K / L)_{i, t}+\gamma(H / L)_{i, t}+b_{i}+\varepsilon_{i, t},
$$

where $g$ is the growth rate function, $Y$ is output, $A$ is TFP, $K$ is capital, $H$ is human capital, and $L$ is labor for country $i$ in year $t$. The country dummy, $b_{i}$, captures any country-specific, time-invariant growth rate differences. The authors choose the following to serve as a proxy for TFP growth: 


$$
g(A)_{i, t}=a_{0}+a_{1} T_{i, t-1}+a_{2}\left[\log (Y / L)_{U S, t-1}-\log (Y / L)_{i, t-1}\right],
$$

where $T$ is a measure of the stock of knowledge relevant for improving TFP and $\log (Y / L)_{U S}-\log (Y / L)_{i}$ is the development gap to the frontier country. The stock of technical knowledge, $T$, is measured by the fraction of the labor force that has completed some form of higher education. Human capital is measured as the mean number of years of schooling, and labor is measured by the number of people aged 15-64. After estimating the model, the authors find that the country dummy variables for New Zealand and Switzerland are not statistically different from zero. They interpret this result as evidence that there are no depressions in these countries and that no "slow growth puzzle' remains." This result squares up well with our theory-based identity that movements in output per working-age person can be attributed to changes in labor and capital inputs and to changes in TFP. Notice that, if $g(A)$ perfectly measured TFP as in (3), the relationship in (16) would also be an identity, and not only the country fixed effects, $b_{i}$, but also the error terms, $\varepsilon_{i, t}$, would disappear.

Given that movements in inputs and TFP can explain output growth, Abrahamsen et al. (2003) ask, as do we, What explains these movements in inputs and TFP? Their answer is that Swiss consumer preferences, particularly over the labor-leisure trade-off, have changed over time in ways that they have not in countries like the United States. It is worth stressing that this point of view is drastically at odds with that taken in this paper. Our point of view is that, while individuals differ in their tastes, people are the same on average, and the institutions that these people face lead to different outcomes. For example, the French devote about 30 percent less time to market activities than do Americans. Does this mean they derive more utility from leisure than do their biologically identical counterparts across the Atlantic Ocean? Rather than assume away the difference in hours worked by appealing to differences in preferences, Prescott (2002) shows that almost all of this difference can be attributed to differences in the two countries' tax systems, and not to different preferences.

In this paper, we have estimated different parameters, $\beta$ and $\gamma$, for New Zealand and Switzerland for the period 1954-70, which we use to analyze the economic performances of these countries over the later period 1970-2000. Our stance is that the differences in these parameters across the two countries are due to differences in institutions, like labor market policies. Differences in institutions across the two countries are relatively unimportant from the perspective of this paper: we are not trying to answer the question of why Switzerland is more prosperous than New Zealand. What is essential for us is to identify any changes in institutions that may have caused the great depressions in New Zealand and Switzerland. 
Appendix A: Data Sources

The data used in this paper are available at http://www.econ.umn.edu/ tkehoe/. Details on the sources of the data follow.

\section{National Accounts}

For both New Zealand and Switzerland, data on nominal and real GDP, gross fixed capital formation, changes in inventories, exports, and imports are from the National Account Statistics of the Organisation for Economic Co-operation and Development (OECD). The New Zealand data are presented in different systems of accounts for the period prior to 1960, the period spanning 1960-70, and the period from 1970 onward. For Switzerland, the data change account systems only in 1970. In both cases, we join the series by ratio splicing. Data on Japan's GDP are from the Economic and Social Research Institute (http://www.esri.cao.go.jp/index-e.html). GDP data for the United States for the years 1948-2000 are from the International Monetary Fund's International Financial Statistics CD-ROM (IFS).

\section{Employment}

The New Zealand employment data from 1960 to 2000 are taken from the OECD's Labor Market Statistics (LMS) database available through their Corporate Data Environment (www1.oecd.org/scripts/cde). The data from 1955 to 1960 are an index of employment in all sectors except agriculture from the United Nation's Statistical Yearbook, various years (UNSY). The index is spliced into the LMS data at 1960. In Switzerland, from 1969 to 2000, employment data are from the International Labor Organization's LABORSTA database (LSTA) (laborsta.ilo.org). Data for 1955-69 are based on an index of manufacturing employment from the UNSY. This index is spliced into the LSTA data at 1969. Data on employment for the United States for 1970-2000 are from the LMS.

\section{Hours Worked}

The data on hours worked for New Zealand 1957-71 and Switzerland 1955-73 are weekly hours worked in manufacturing from the UNSY. Data for New Zealand 1971-98 and Switzerland 1973-91 are from LSTA and are weekly hours in manufacturing. The data for New Zealand 1999-2000 and Switzerland 1991-2000 are from the LMS and are average yearly hours worked.

\section{Population}

For both countries, populations from 1956 to 2000 are from the LMS. For the year 1955 , the data are from the IFS. For both countries, data on the population aged 15-64 for 1956-2000 are from the LMS.

\section{Terms of Trade}

For New Zealand and Switzerland, import and export price deflators for the years 
1970-2000 are created from data on real and nominal imports and exports from the OECD's National Account Statistics. The export deflator is divided by the import deflator to form the terms of trade. For New Zealand, the data on the terms of trade from 1955 to 1970 are unit price indexes for imports and exports. These indexes are from the IFS.

\section{Trade}

The data on New Zealand-United Kingdom trade are from the OECD's International Trade by Commodity Statistics database.

\section{Historical Data}

Data on GDP for New Zealand and Switzerland for the years prior to 1955 are from Maddison 1995, 2001. Data on population for New Zealand and Switzerland before 1956 are from Maddison 1995. The population data are spliced into working-age population in 1956 to create the working-age population series used in Figures 2 and 3. Data on GDP for the United States from 1920-48 are from Maddison 1995. Data on working-age population for the United States are from the U.S. Census Bureau. The working-age population data for Italy are from the World Bank's World Development Indicators CD-ROM for the years 1960-2000. Population data for Italy are taken from Maddison 1995 for the years 1920-60. These data were spliced into the working-age population data in 1960 to create the working-age population series used in Figure 4. Data on GDP for Italy are from Maddison 1995, for 1920-94, and from the IFS for the years 1994-2000.

\section{Appendix B: Robustness of Output Measures}

In this appendix we consider alternative measures of the population and GDP to evaluate the robustness of these depressions, and discuss some issues in the data available.

\section{Population Measurement}

Measuring population as those aged 15-64, rather than the total population, makes a difference in our results only if there has been a change in the fraction of 15-64 year-olds in the total population. We plot detrended GDP per population measure as well as GDP per working-age person in Figures B1 and B2. The demographics in Switzerland have been particularly stable in the last half century; the fraction of the total population aged 15-64 was 0.66 in 1955 and 0.68 in 2000. Given this observation, it is not surprising that Switzerland's GDP per person differs only slightly when computed using different measures of the population. In contrast, the share of $\mathrm{New}$ Zealand's working-age population in the total population went from 0.59 in 1970 to 0.65 in 1984 and has stayed stable since then. Consequently, we see some difference in the GDP measures when considering different populations in New Zealand. 
Figure B1. New Zealand: Different measures of population

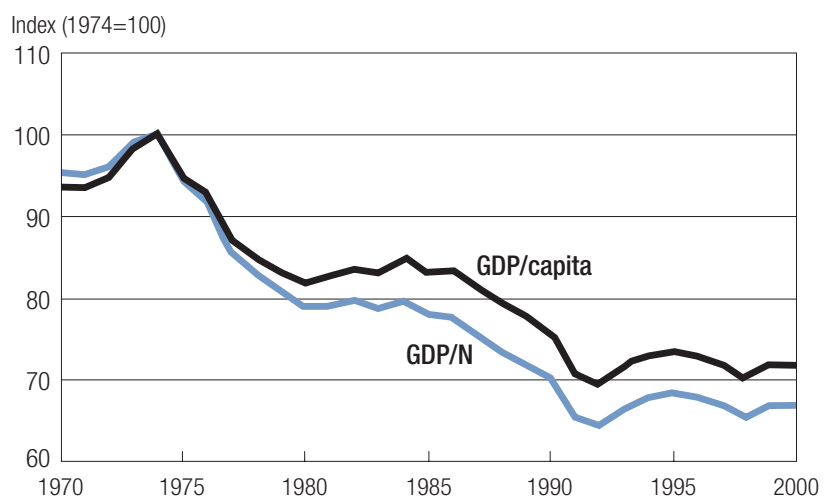

Figure B2. Switzerland: Different measures of population

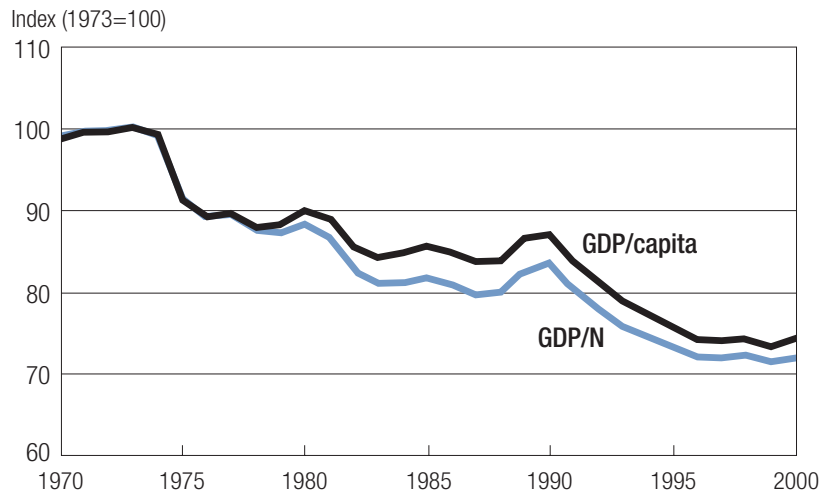

\section{GDP Measurement and the Terms of Trade}

Recent work by Kohli (2004) suggests that using real GDP as a measure of output in an open economy subject to terms-of-trade fluctuations may understate growth. Kohli argues that changes in the terms of trade can lead to a decrease in measured real GDP if the terms of trade are treated as a price phenomenon rather than a real effect. The terms of trade are defined as the price of a country's exports divided by the price of a country's imports. One method of accounting for changes in the terms of trade is by deflating the net exports (exports minus imports) by the implicit import price deflator, rather than deflating exports and imports separately. This method of computing GDP is known as command basis GDP. Rather than use the command basis measure of GDP employed by the U.S. Bureau of Economic Analysis and other 
national statistics agencies, Kohli (2004) uses a Törnqvist measure of real value added that makes a similar conceptual adjustment. He concludes that over the period 1986-2000, a Laspeyres real GDP index similar to the one we use understates New Zealand's growth by 5.9 percentage points compared to his measure. For Switzerland, whose terms of trade have increased rapidly throughout this period, Kohli (2004) finds that the conventional GDP measure misses 13 percentage points of growth compared to his measure.

To evaluate the effects of this possible mismeasurement, we compute measures of command basis GDP per working-age person. Our command basis GDP is calculated by deflating the consumption and investment portions of the national accounts by their implicit price deflators, whereas we deflate net exports by the implicit price deflator for imports. Figures B3 and B4 display detrended comparisons of conventional GDP

Figure B3. New Zealand: Accounting for terms of trade

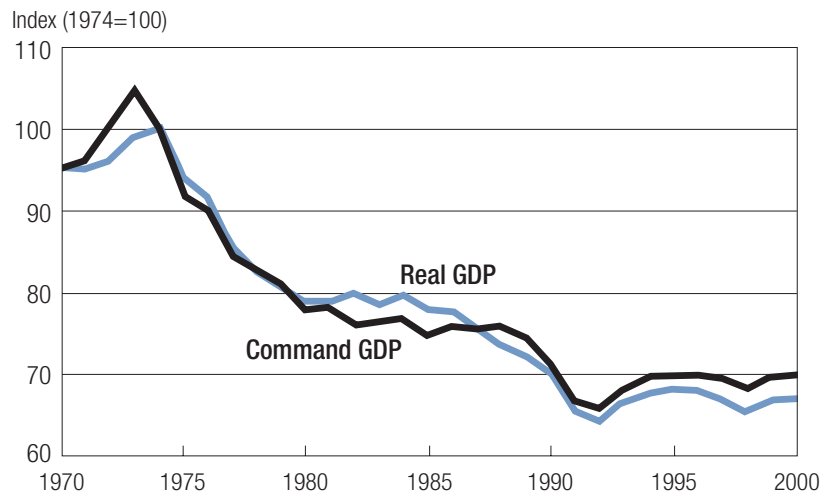

Figure B4. Switzerland: Accounting for terms of trade

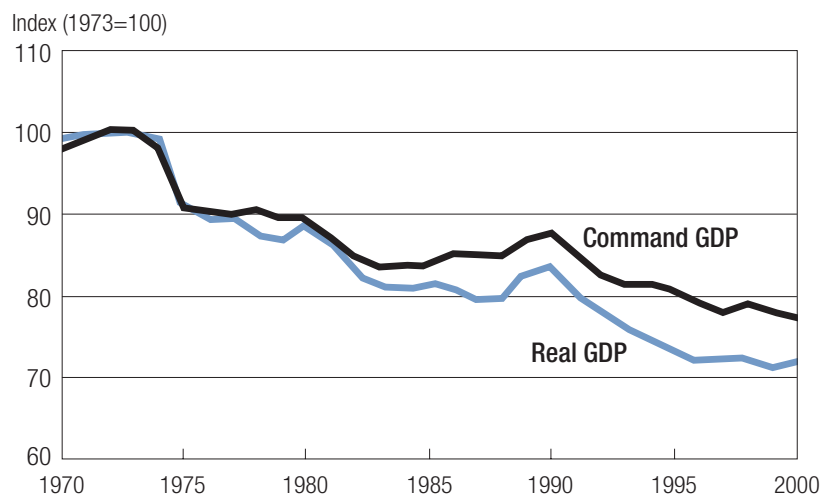


per working-age person and our computation of command basis GDP per working-age person. In Switzerland, where the terms of trade increased strongly through the 1980s and 1990s, the command basis GDP diverges from the traditionally measured series. Accounting for the terms of trade in this manner reduces the fall in trend-corrected output by 5 percentage points. Output is still growing slower than trend, however. For New Zealand, the differences in the two series are smaller, as increases in the terms of trade in the 1990s partially offset the decreases in the 1980s. Notice that, as in Kohli (2004), our command basis GDP does grow by 6.0 percentage points more than the conventional measure between 1986 and 2000 because of the improvement of the terms of trade over this period seen in Figure 12.

\section{Summary}

The sources of mismeasurement just discussed may lead to small changes in the appearance of the GDP per working-age person plots presented in Figure 5 and Figure 6, but none of these possible sources of mismeasurement reverses our findings. No matter how we choose to measure it, New Zealand and Switzerland have failed to return to their trend-corrected levels of output. For reasons yet to be fully explained, these two countries, which grew on, or above, trend for the twenty years preceding 1974, have fallen into a thirty-year slump in output growth-modern great depressions.

\section{Notes}

(C) 2003, Timothy J. Kehoe and Kim J. Ruhl. We have benefited greatly from the discussions surrounding the "Great Depressions: New Zealand and Switzerland in the Late Twentieth Century" workshop at Victoria University of Wellington, February 2003. We are also grateful to seminar participants at the New Zealand Institute of Economic Research and the University of Auckland. We would like to thank Phillip Bishop, Phil Briggs, Stephen Burnell, Brian Easton, Tim Hazledine, Ralph Lattimore, John McDermott, Andrew Philpott, Dennis Rose, and Mark Walton for insightful discussion and valuable references. We also thank two anonymous referees for helpful comments. The data used in this paper are available at http://www.econ.umn.edu/ tkehoe/. An earlier version of this paper, entitled "Recent Great Depressions: Aggregate Growth in New Zealand and Switzerland, 1973-2000," appeared in New Zealand Economic Papers, Vol. 37 (2003).

1. This specific comparison is based on the GDP per adult equivalent series in the Penn World Tables. Switzerland's GDP per adult equivalent, expressed in Penn World Table constant 1996 international prices, was $\$ 23,332$ - 22 percent larger than the United States, the second richest country in 1970 - and \$28,796 in 2000. New Zealand's GDP per adult equivalent was $\$ 16,242$ in 1970 and $\$ 21,675$ in 2000 .

2. See the work of Evans et al. (1996) for a survey of the reforms and their initial outcomes.

3. Note that because of the rapid aging of Japan's population, it makes a difference how we define working age. If we define working age as 20-69 years, for example, the drop in real GDP per working-age person between 1991 and 2002 was about 14 percent. The age structures 
of the populations of New Zealand and Switzerland are more stable than that of Japan. This point is addressed in Appendix B.

4. The crude method is simply $1-\alpha=$ compensation of employees/(GDP-net indirect taxes).

5. It may be the case that returns to land are more important in New Zealand than they are in countries like the United States, and that this accounts for the low measured depreciation and the low measured labor share. This is a topic that merits further study.

6. The growth rates can be expressed as approximately percentage growth rates because the difference in log values will approximate percentage changes for small changes in the variables. The decomposition in (6) has the advantage of being additive.

7. The comparison of our results with those of Kohli (2003) are somewhat difficult because he follows the convention employed by Statistics New Zealand of using data for years that end on March 31, whereas we follow the more common convention employed, for example, by the OECD of using data for years that end on December 31 .

\section{References}

Abrahamsen, Yngve; Roland Aeppli; Erdal Atukeren; Michael Graff; Christian Müller; and Bernd Schips. 2003. The Swiss disease: Facts and artefacts. Working Paper 71. Swiss Federal Institute of Technology.

Belich, James. 1996. Making peoples: A history of the New Zealanders. Honolulu: University of Hawaii Press.

2001. Paradise reforged: A history of the New Zealanders. Honolulu: University of Hawaii Press.

Briggs, Phil. 2003. Looking at the numbers: New Zealand's economic history. Research Monograph 69. Wellington: New Zealand Institute of Economic Research.

Cooley, Thomas F., and Edward C. Prescott. 1995. Economic growth and business cycles. In Frontiers of business cycle research, ed. Thomas F. Cooley, 1-38. Princeton, NJ: Princeton University Press.

Dalziel, Paul, and Ralph Lattimore. 2001. The New Zealand macroeconomy: A briefing on the reforms and their legacy. 4th ed. Melbourne: Oxford University Press.

de Cordoba, Fernandez Gonzalo, and Timothy J. Kehoe. 2000. Capital flows and real exchange rate fluctuations following Spain's entry into the European Community. Journal of International Economics 51 (June): 49-78.

Easterly, William; Michael Kremer; Lant Pritchett; and Lawrence H. Summers. 1993. Good policy or good luck? Country growth performance and temporary shocks. Journal of Monetary Economics 32 (December): 459-83.

Easton, Brian. 1997. In stormy seas: The post-war New Zealand economy. Dunedin: University of Otago Press.

Evans, Lewis; Arthur Grimes; Bryce Wilkinson; and David R. Teece. 1996. Economic reform in New Zealand 1984-95: The pursuit of efficiency. Journal of Economic Literature 34 (December): 1856-1902. 
Gollin, Douglas. 2002. Getting income shares right. Journal of Political Economy 110 (April): 458-74.

Grimes, Arthur. 1991. The effects of inflation on growth: Some international evidence. Weltwirtschaftliches Archiv 127 (4): 631-44.

Hall, Viv B. 1996. Economic growth. In A study of economic reform: The case of New Zealand, ed. Brian Silverstone, Alan Bollard, and Ralph Lattimore, 31-71. Amsterdam: North-Holland.

Hawke, Gary R. 1985. The making of New Zealand: An economic history. Cambridge: Cambridge University Press.

Hawke, Gary R., and Ralph Lattimore. 1999. Visionaries, farmers, and markets: An economic history of New Zealand agriculture. Working Paper 1. NZ Trade Consortium.

Hviding, Ketil. 1998. Switzerland's long run growth slowdown. In Switzerland: Selected issues and statistical appendix, ed. Albert Jaeger, Ketil Hviding, and Victor Valdivia. Staff Country Report 98/43. International Monetary Fund.

Kehoe, Timothy J., and Kim J. Ruhl. 2005. Is Switzerland in a Great Depression? Review of Economic Dynamics 8 (June): 759-75.

Kohli, Ulrich. 2003. Terms of trade, real GDP, and real value added: A new look at New Zealand's growth performance. New Zealand Economic Papers 37 (June): 41-66.

. 2004. Real GDP, real domestic income, and terms-of-trade changes. Journal of International Economics 62 (January): 83-106.

Lambelet, Jean-Christian, and Alexander Mihailov. 2000. A note on Switzerland's economy: Did the Swiss economy really stagnate in the 1990s, and is Switzerland really all that rich? Manuscript. Créa Institute, Lausanne University.

Lattimore, Ralph, and Paul Wooding. 1996. International trade. In A study of economic reform: The case of New Zealand, ed. Brian Silverstone, Alan Bollard, and Ralph Lattimore, 315-53. Amsterdam: North-Holland.

Maddison, Angus. 1995. Monitoring the world economy, 1820-1992. Development Centre Studies. Paris: Organisation for Economic Co-operation and Development.

- 2001. The world economy: A millennial perspective. Development Centre Studies. Paris: Organisation for Economic Co-operation and Development.

Parente, Stephen L., and Edward C. Prescott. 2002. Barriers to riches. Cambridge, MA: MIT Press.

Philpott, Bryan P. 1993. Data for sectoral productivity analysis and some preliminary results for 1978-1993. Paper 256. Research Project on Economic Planning, Victoria University of Wellington.

- 1994. Production functions and productivity growth in New Zealand 1959/60-1994/95. Paper 260. Research Project on Economic Planning, Victoria University of Wellington.

Prescott, Edward C. 1998. Needed: A theory of total factor productivity. International Economic Review 39 (August): 525-51.

2002. Prosperity and depression: 2002 Richard T. Ely lecture. American Economic Review 92 (May): 1-15. 
Great Depressions: New Zealand and Switzerland

Kehoe, Ruhl

Rose, Dennis. 1985. Employment and the economy. Planning Paper No 21. New Zealand Planning Council.

Sheldon, George. 2000. The impact of foreign labor on relative wages and growth in Switzerland. Labor Market and Industrial Organization Research Unit (FAI), University of Basel.

2001. Foreign labor employment in Switzerland: Less is not more. Labor Market and Industrial Organization Research Unit (FAI), University of Basel.

Silverstone, Brian; Alan Bollard; and Ralph Lattimore. 1996. Introduction to A study of economic reform: The case of New Zealand, ed. Brian Silverstone, Alan Bollard, and Ralph Lattimore, 1-29. Amsterdam: North-Holland. 
